\title{
Does Participative Leadership Promote Innovative Work Behavior: The Moderated Mediation Model
}

\author{
Tasneem Fatima ${ }^{1}$, Mehwish Majeed ${ }^{2}$, Imran Saeed ${ }^{3}$
}

\begin{abstract}
Keeping in view the social learning theory, the current study aims to examine the impact of participative leadership on innovative work behavior with mediating role of employee commitment to change. The change readiness is taken as a moderator between participative leadership and employee commitment to change. This study used convenience sampling technique. A total of 352 complete responses were taken from service sector employees of Pakistan in a time lagged design. SPSS 20, AMOS 18 and Process Marco by Hayes were used to complete the analysis. Results indicate that participative leadership leads to innovative work behavior and employee commitment to change mediates this relationship. Moderation hypothesis is also proved to indicate that employees with higher change readiness are more likely to show commitment to change under a participative leader. Limitations as well as future directions are given at the end. Theoretical and practical implications are also discussed.
\end{abstract}

\section{Introduction}

The $21^{\text {st }}$ century has seen a massive change in the ways businesses operate. Globalization, technological advancements, and tough market conditions are few of the many factors that have motivated the business organizations to focus more on innovation (Akram, Lei \& Haider, 2016). This is particularly true for service sector organizations as they have to face a huge amount of competition due to rapid technological changes (Archibugi, Filippetti \& Frenz, 2013; Barrett, Davidson, Prabhu \& Vargo, 2015). There is a lot of literature present on organizational innovation. However, only a limited number of studies have identified the organizational factors that can lead to an increase in organizational innovation (Hogan \& Coote, 2014; Akram et al., 2016). One such factor is leadership style as it plays a vital role in making or breaking any organization. For an organization to achieve innovation, its leadership must follow a positive approach as innovation can't breathe in the negative environment (Donate,

1 Assistant Professor, International Islamic University, Islamabad. Email: tasneem.fatima@iiu.edu.pk 2 PhD Scholar, International Islamic University, Islamabad. Email: mehwish.phdmgt70@iiu.edu.pk 3 Lecturer IBMS, University of Agriculture, Peshawar. Email: Imranktk1984@gmail.com

\begin{tabular}{lll} 
ARTICLE HISTORY & & \\
\hline 15 Aug, 2017 Submission Received & 20 Sep, 2017 & First Review \\
\hline 27 Sep, 2017 Revised Version Received & 17 Oct, 2017 & Second Review \\
\hline 30 Oct, 2017 Revised Version Received & 10 Nov, 2017 & Accepted
\end{tabular}


\& Pablo, 2015). Participative leadership style is a positive type of leadership style in which the leader gives employees the opportunity to participate in decision making and problem-solving through encouragement, support and influence (Somech, 2006). Participative leaders give employees a sense of responsibility by giving them role in decision making (Sauer, 2011). Followers of a participative leader are more likely to show good performance, organizational citizenship behavior and various other positive behaviors (Miao, Newman \& Huang, 2014). Talking about positive employee behaviors, employee commitment to change has gained significant importance during the last few years. It is mainly because of the external pressure on the organization to adopt change for long-term survival and growth (Michaelis, Stegmaier \& Sonntag, 2010).

Employee commitment to change is referred to as a positive employee behavior in which he supports the change based on his faith that the change is beneficial (Herscovitch \& Meyer, 2002). Those employees who feel committed to change are more likely to show change related behavior (Raffert \& Restubog, 2010). Innovative work behavior is one of the many change oriented behaviors as it involves bringing a change in the way business works (Madrid, Patterson, Birdi, Leiva \& Kausel, 2014). Innovative work behavior is defined as employee behavior intended to develop and implement new products, services, ideas, process or procedures within his department or organization (De Jong \& Den Hartog, 2008). Innovative work behavior involves change and for change to occur, it is very important that employees are ready for the change (Kwahk \& Lee, 2008). In addition to employee commitment to change, change readiness has also emerged as a variable of great interest for organizational change researchers. Organizational change readiness is an employee's belief that the organization has the ability to bring proposed change, change is relevant to the business of the organization, top management is motivated to bring change and change is beneficial for the organization (Holt, Armenakis, Field \& Harris, 2007).

The current study has linked leadership style with the commitment to change and innovative work behavior, a combination less investigated. The major rationale behind studying participative leadership with employee commitment to change and innovative work behavior is to investigate the role positive leadership style plays in developing change and innovative work behavior among employees. Leadership literature is in its adulthood; however, there is a very little consensus as to what leadership is and how it works (Akram, et al, 2016). Participative leadership is still in its infancy, there is a need to study the mechanism through which participative leadership result in different employee outcomes (Miao et al, 2013). In their study, Lam, Huag and Chan (2015) also recommended future researchers to explore different moderating and mediating mechanism through which participative leadership leads to different outcomes. Despite a lot of research, there is still a lack of consensus as to which factors 
lead to innovative work behavior (Akram et al, 2016). A large number of studies have examined the antecedents of employee commitment to change. However, there is very little knowledge about the outcomes of this positive employee behavior (Trivisonno \& Barling, 2016).

\section{Literature Review}

Innovative work behavior has gained significant importance lately, mainly due to the rapidly changing global market and increased competition (Shanker, Bhanugopan, Heijdem \& Farrell, 2017). It is also obvious from the current trends in recruitment as a majority of the organizations check the creative and cognitive abilities of the applicants to make sure their workforce shows innovative work behavior (Delgadova, Gullerova \& Ivanova, 2017). This has also led organizations to change their leadership style as leaders play a key role in determining the productivity of employees (Strom, Sears \& Kelly, 2014).

Organizations are now shifting from transactional leadership styles to modern leadership styles. One such example is participative leadership, a style highly known and appreciated for bringing a positive change in the organization (Asmawi, Rahim \& Zainuddin, 2015). Participative leaders don't hesitate to share their power with their employees by encouraging them to take part in decision making (Benoliel \& Somech, 2014). It is due to this positive behavior that employees automatically start showing positive outcomes in the form of good performance, job satisfaction and other positive outcomes (Miao et al, 2014). In other words, employees learn from their leader and try to imitate his positive behavior by showing positive outcomes like innovative work behavior. Keeping in view this, the current study proposes that employees show innovative work behavior under a participative leader (Bandura, 1977).

$\mathrm{H}_{1}$ : Participative leadership is positively linked to employee innovative work behavior.

Participative leadership style involves shared decision making and joint influence, both of which are necessary for bringing change in the organization (Pearce \& Sims, 2002). Those employees who are given a part in the decision making feel privileged as it gives them the feeling that their leader considers them an important part of their organization (Somech, 2005). This results in employee commitment to change. Social learning framework also suggests that leaders act as a role model for the employees (Bandura, 1977). The positive behavior of a leader motivates the employees to follow his footsteps. When employees repeatedly observe that their leader is giving them responsibility by allowing them to take part in decision making then they automatically start replicating the positive behavior of their leader by showing their commitment 
towards change (Bandura, 1978). In the light of social learning perspective and the existing literature on participative leadership as well as organizational commitment, the current study proposes that employees learn from their leaders and that those employees, who are given shared influence, support and part in decision-making show commitment to change.

$\mathrm{H}_{2}$ : Participative leadership is positively associated with employee commitment to change.

Employee commitment to change is itself a driving factor for several positive outcomes like innovation, role clarity and shared customer values (Trivisonno et al, 2016; Lumbasi, K'Aol \& Ouma, 2016). When employees feel committed to change then they do everything in their hand to bring a positive change in the organization (Parish, Cadwallader \& Busch, 2008). Employees do what they observe. When they learn positive behavior from their leaders then they automatically start displaying positive behavior (Bandura, 1977). Based on this social learning perspective, the current study proposes that those employees who are committed towards change are more likely to show positive behavior that is innovative work behavior.

$\mathrm{H}_{3}$ : There is a positive association between employee commitment to change and innovative work behavior.

The positive side of participative leadership is that these leaders don't impose their decisions on employees. Instead, they take suggestions and recommendations from the employees and take decisions on the basis of consensus (Somech \& Wenderow, 2006). In other words, these leaders ensure the involvement of their employees in routine as well as important business matters. Employees not only feel honored but also motivated that their leader respects their views and treat them as equal members of the organization (Kim, 2002). They observe their leader and try to imitate his behavior by displaying positive emotions at the workplace. This is what increases their commitment to change (De Jong \& Hartog, 2007). It is due to this increased commitment that employees start displaying innovative work behavior. In short, employees learn from their environment by observing their leader and this learning molds their behavior (Bandura, 1977). Observation of positive behavior at the workplace on repeated basis results in the adoption of this behavior. Hence, positive behavior leads to positive outcomes as a result of cognitive learning processes (Bandura, 1977). Based on this, it is safe to assume that participative leadership is positively associated with innovative work behavior through employee's commitment to change.

$\mathrm{H}_{4}$ : Participative leadership is positively linked to innovative work behavior and employee commitment to change mediates this relationship. 
The careful analysis of the existing literature indicates that organizational change is a complex process that not only requires right leadership style but also various other factors. One such factor is change readiness. The research articles on organizational change give extra emphases on making employees ready for change before actually initiating the change (Madsen, Miller \& John, 2005). Change readiness is operationalized at multilevel, but the current study has taken it at an individual level. It refers to the belief among employees that they are ready for the change, the given change is necessary for the organization, the leader is fully committed towards the change and that the proposed change will yield positive outcomes (Holt et al, 2007). Those employees who are ready for organizational change are more likely to show commitment towards change. Employees working under a participative leader are more likely to show change readiness as participative leaders listen to their followers and answer their concerns related to business matters (Dam, Oreg \& Schyns, 2008). Social learning perspective also suggests that employees learn from their surroundings and it is due to this continuous learning process that they imitate the behavior of their leader (Bandura, 1978). Based on this, the current study proposes that those employees who are ready for change are more likely to show commitment towards the change under a participative leader. And employees with higher organizational readiness to change are more likely to show commitment to change leading to increased innovative work behavior under a participative leader as compared to employees who are not ready for the change.

$H_{5}$ : Change readiness moderates the relationship between participative leadership and employee commitment to change such that employees with higher change readiness will show higher commitment to change under a participative leader.

$H_{6}$ : The indirect impact of participative leadership on innovative work behavior via employee commitment to change increases in the case of higher change readiness as compared to lower change readiness

Figure 1 shows the proposed model. As per the model, participative leadership results in employee commitment to change which leads to employee innovative work behavior and employee change readiness moderates the relationship between participative leadership and employee commitment to change.

\section{Research Design and Methodology}

The current study aimed to explore the impact of participative leadership on innovative work behavior with mediating role of organizational commitment to change and moderating role of change readiness. Employees working in the service sector of Pakistan were taken as the study population whereas data for the study was 


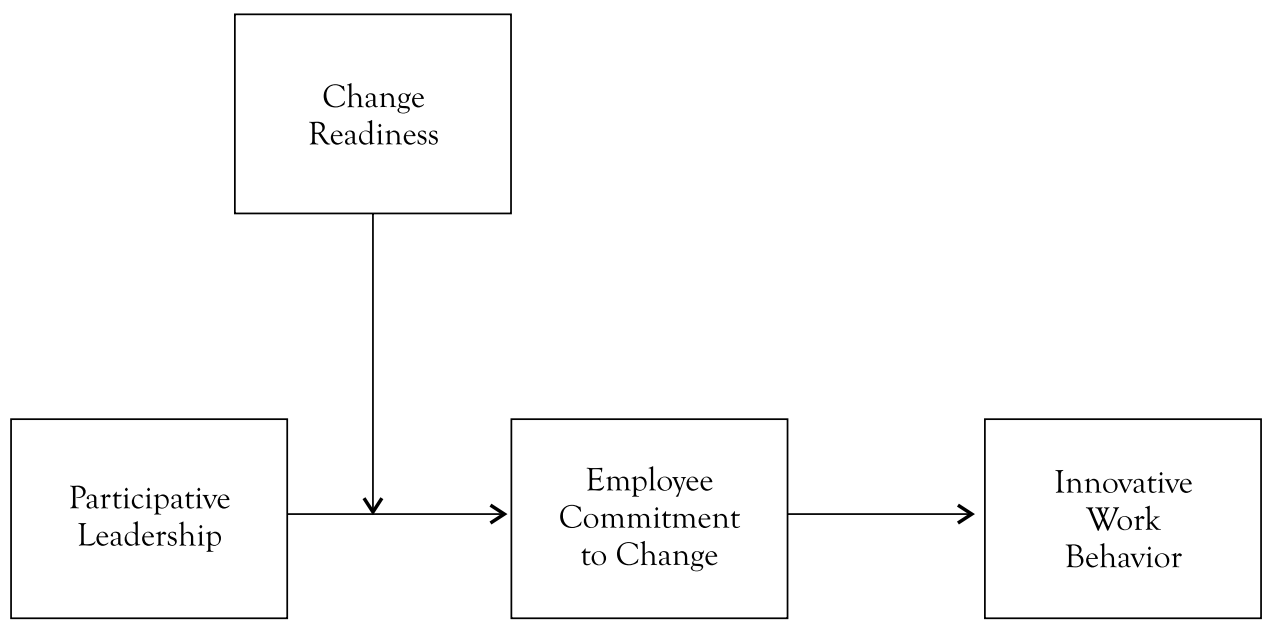

Figure 1: Theoretical Framework

taken from the twin cities. Due to the lack of official information regarding the total population of telecom sector of Pakistan, the current study used the non-probability sampling technique, in that we opted for convenience sampling method. Personal and official contacts were used to contact the respondents. The authors personally administered the questionnaires in order to answer the queries of the respondents at the time of filling the survey questionnaires.

It was a time-lagged study and data was collected in three waves each having a gap of ten days. Data for the independent variable that is participative leadership and moderator namely change readiness was collected at time 1. Employee commitment to change was tapped at time 2 and data for innovative work behavior was collected at time 3. Data was collected through a survey in which respondents were asked to give their opinion by filling the questionnaire. Confidentiality of the respondents was ensured so that they can share their honest opinion. A total of 470 questionnaires were rotated out of which only 394 questionnaires were returned back. After discarding questionnaire having missing values and unengaged responses, 352 responses were left on which data analysis was done.

\subsection{Measures}

Participative Leadership was measured by using a 3-Item scale developed by Anold, Arad, Rhoades and Drasgow (2000). The sample items include "Encourages work group members to express ideas/suggestions". The alpha reliability for this scale was 0.74 . The current study has taken 9-item scale for measuring innovative work behavior. This scale was taken from (Scott \& Bruce, 1994). The sample item states that "Searches out new technologies, processes, techniques, and/or product ideas." 
The Cronbach's alpha for this scale was 0.89 . Readiness for change was measured by using a 6-item scale of Holt et al 2007. The sample item states "I have the skills that are needed to make this change work." The value for Cronbach alpha was 0.75 for this scale. Employee commitment was tapped by using the scale of (Mowday, Steers $\&$ Porter, 1979). The Cronbach's alpha for this scale was 0.75 . This scale contained 7 items. The sample item includes "I am willing to put in a great deal of effort beyond that normally expected in order to help this organization be successful." Items for all the variables were taken at 7-point likert scale ranging from strongly disagree to strongly agree. All the scales used in this study are well validated. Their convergent, discriminant and content validity is well established and their reliability values also fall within the standard range.

\section{Data Analysis Techniques}

Data analysis was done by using SPSS 20 software package, AMOS 20 and Process Macro by Hayes. Questionnaire with unengaged responses were discarded. Missing values were treated before carrying out the analysis. A total of 352 fully complete questionnaires were left for data analysis. Data was entered into the SPSS 20 package for analysis purposes.

We followed the two-step strategy of Anderson and Gerbing (1988) to test the proposed model. According to this strategy, we examined the measurement model for all the variables under study. After getting a better fit of the full measurement model, the path model of the proposed mediation was tested.

\subsection{Control variables}

ANOVA and correlation test were conducted to identify the control variables. After careful analysis, it was found that gender, organization type, marital status and professional experience were significantly related with dependent variable, mediator and moderator. Therefore, these four variables were controlled while doing structural equation modeling and moderation analysis to make sure their variance remain controlled during analysis. Several researchers have suggested controlling those variables other than variables under study which are showing a significant relation with the variables under study (Becker, 2005).

Table 1 contains the demographic details of the respondents. Questions for age, professional experience, and total experience were left open-ended so their demographics are not included in the table. The age of the respondents ranged between 19 and 50 years. The respondents had a professional experience between 5 months and 12 years, whereas their total work experience ranged between 8 months and 28 years. 
Table 1: Demographic Details of Respondents

\begin{tabular}{|c|c|c|}
\hline Demographic Attributes & Frequency & Percentage \\
\hline \multicolumn{3}{|l|}{ Gender } \\
\hline Male & 238 & 67.6 \\
\hline Female & 114 & 32.4 \\
\hline \multicolumn{3}{|l|}{ Organization Type } \\
\hline Government & 18 & 5.1 \\
\hline Private & 334 & 94.9 \\
\hline \multicolumn{3}{|l|}{ Department Type } \\
\hline HR, Admin, Mgt & 103 & 29.3 \\
\hline Finance, Acc, Audit & 110 & 31.3 \\
\hline IT, SE & 96 & 27.3 \\
\hline Operations, Logic, Supply Chain & 43 & 12.2 \\
\hline \multicolumn{3}{|l|}{ Designation } \\
\hline Lower Management & 91 & 25.9 \\
\hline Middle Management & 159 & 45.2 \\
\hline Top Management & 91 & 29.0 \\
\hline \multicolumn{3}{|l|}{ Specifications } \\
\hline HR, Admin, Mgt & 112 & 31.8 \\
\hline Finance, Acc, Audit & 108 & 30.7 \\
\hline IT, SE & 86 & 24.4 \\
\hline Operations, Logic, Supply chain & 46 & 13.1 \\
\hline
\end{tabular}

$67.6 \%$ of the employees were male whereas remaining respondents were female. $94.9 \%$ of the respondents were working in private companies whereas the remaining $5.1 \%$ were working in the public organizations. The analysis of demographics also indicated that $29.3 \%$ of the total respondents were serving in human resource, administrative and management posts, whereas $31.3 \%$ of them were working in the finance, audit and accounting department. The remaining $27.3 \%$ of employees belonged to information technology and software whereas $12.2 \%$ were working in operations, logics, and supply department. Precisely, $25.9 \%$ of the total respondents were front line managers, $45.2 \%$ of them were middle managers and $29.0 \%$ were and top managers.

Table 2 contains values for mean, standard deviation and reliability. The values for mean lie between 3 and 5 which fall under normal range and the standard deviation is also greater than 0.5 . Both these things show that there is not an issue of common method bias in the data. The value for reliability statistics also fall under the normal 
Table 2: Descriptive Statistics, Correlation and Reliabilities

\begin{tabular}{|c|c|c|c|c|c|c|c|}
\hline & Mean & SD & AVE & 1 & 2 & 3 & 4 \\
\hline 1. PLT1 & 5.29 & 1.35 & .65 & $(.84)$ & & & \\
\hline 2. CRT1 & 5.06 & 0.90 & .37 & .04 & $(.83)$ & & \\
\hline 3. EC2CT2 & 3.82 & 1.23 & .47 & $.26^{* *}$ & $.25^{* *}$ & $(.85)$ & \\
\hline 4. IWBT3 & 4.28 & 4.28 & .64 & $.41^{* *}$ & $.39^{* *}$ & $.55^{* *}$ & $(.91)$ \\
\hline
\end{tabular}

range. Correlation values also indicate that all variables except change readiness are correlated with each other.

${ }^{* *}$ Correlation is significant at the 0.01 level (2-tailed).

$\mathrm{N}=352$

$\mathrm{T} 1=$ time $1 ; \mathrm{T} 2=$ time $2 ; \mathrm{T} 3=$ time 3

$\mathrm{PL}=$ Participative Leadership; CR: Change Readiness; EC2C = Employee Commitment to Change; IWB = Innovative Work Behavior

Table 3: Model Fit Indices for CFAs

\begin{tabular}{|c|c|c|c|c|c|c|c|c|c|}
\hline Model Test & $\chi^{2}$ & df & $\chi^{2} / \mathrm{df}$ & CFI & NFI & GFI & TLI & RMR & $\begin{array}{l}\text { RM- } \\
\text { SEA }\end{array}$ \\
\hline \multicolumn{10}{|l|}{ For T1 } \\
\hline 1 factor (PL and CR combined) & 534 & 43 & 12.4 & .73 & .72 & .80 & .59 & .31 & .18 \\
\hline 2 factor (PL, CR) & 88.3 & 46 & 1.92 & .97 & .95 & .96 & .96 & .10 & .05 \\
\hline \multicolumn{10}{|l|}{ IV and Mediators } \\
\hline $\begin{array}{c}1 \text { factor (PL and EC2C Com- } \\
\text { bined) }\end{array}$ & 487.1 & 30 & 16.2 & .77 & .76 & .77 & .66 & .33 & .20 \\
\hline 2 factor (PL, and CR) & 72.9 & 28 & 2.60 & .97 & .96 & .95 & .96 & .15 & .06 \\
\hline \multicolumn{10}{|l|}{ IV,Mediator,DV } \\
\hline $\begin{array}{c}1 \text { factor (PL,EC2C and IWB } \\
\text { Combined) }\end{array}$ & 1471 & 1.4 & 14.1 & .65 & .63 & .56 & .59 & .34 & .19 \\
\hline 3 factor ( PL,EC2C and IWB) & 245.8 & 93 & 2.64 & .96 & .93 & .92 & .95 & .19 & .06 \\
\hline \multicolumn{10}{|l|}{ All Variables } \\
\hline $\begin{array}{c}1 \text { factor (PL, EC2C, IWB and } \\
\text { CR Combined) }\end{array}$ & 1844 & 260 & 7.09 & .70 & .67 & .67 & .66 & .28 & .13 \\
\hline $\begin{array}{c}4 \text { factors ( PL, EC2C, IWB and } \\
\text { CR) }\end{array}$ & 532.2 & 255 & 2.08 & .94 & .90 & .89 & .94 & .19 & .05 \\
\hline \multicolumn{10}{|l|}{$\mathrm{N}=352$} \\
\hline \multicolumn{10}{|l|}{$\mathrm{T} 1=$ time 1} \\
\hline
\end{tabular}

Best model fits are given in bold 
Table 3 contains the results of Harman's single factor test. Many researchers are of the view that this test is a good way of checking the common method bias (Podsakoff, MacKenzie, Lee \& Podsakoff, 2003). In this method, all items for all the variables are loaded on a single factor and its model fit is checked which is then compared with the 2 factor, 3 factor and 4 factor models depending on the number of a variable under study. In the current study, Herman's test is done for time 1variables which include participative leadership and change readiness, independent variable and mediator, independent variable, mediator and dependent variable and lastly 4 factor models containing all the variables under study. The results of 2 factor, 3 factor and 4 factor are better with model fit indices showing satisfactory values. The results for good fit and given in bold.

Table 4: Comparison of Alternative Structural Models

\begin{tabular}{|c|c|c|c|c|c|c|c|c|c|}
\hline Model Test & $\chi 2$ & Df & $\chi 2 /$ df & CFI & NFI & GFI & TLI & RMR & $\begin{array}{c}\text { RM- } \\
\text { SEA }\end{array}$ \\
\hline $\begin{array}{c}\text { Hypothesized Model : Indi- } \\
\text { rect path from PL to IWB } \\
\text { through EC2C }\end{array}$ & 328 & 147 & 2.2 & 0.95 & .92 & .91 & .94 & .16 & .05 \\
\hline $\begin{array}{c}\text { Alternative Model 1: Direct } \\
\text { paths from PL to EC2C and } \\
\text { IWB }\end{array}$ & 528 & 150 & 3.52 & .90 & .87 & .88 & .88 & .44 & .08 \\
\hline $\begin{array}{c}\text { Alternative Model 2: Direct } \\
\text { Path from PL and EC2C to } \\
\text { IWB }\end{array}$ & 601 & 154 & 3.90 & .89 & .85 & .85 & .86 & .27 & .09 \\
\hline
\end{tabular}

$\mathrm{N}=352$

$\mathrm{PL}=$ Participative Leadership; CR: Change Readiness; EC2C = Employee Commitment to Change; IWB = Innovative Work Behavior

Gender, Designation, Marital Status and Professional Experience is controlled in all models.

Table 4 contains the comparison of the hypothesized model and two alternative models. The results of the model fit indicate that the hypothesized model has a better fit compared to the alternative models.

Table 5: Standardized Regression Weights of Paths in the Hypothesized Model

\begin{tabular}{|c|c|c|c|}
\hline & Proposed causal relation & $\beta$ & S.E \\
\hline H1 & Participative leadership $\rightarrow$ Job Performance & $0.71^{* * *}$ & 0.08 \\
\hline H2 & Participative leadership $\rightarrow$ Employee commitment to change & $0.62^{* * *}$ & .10 \\
\hline H3 & Employee commitment to change $\rightarrow$ Innovative work behavior & $0.51^{* * *}$ & .04 \\
\hline
\end{tabular}

Note: $\dagger p<.10 ;{ }^{*} \mathrm{p}<.05 ;{ }^{* *} \mathrm{p}<.01 ;{ }^{* * *} \mathrm{p}<.001$

Note: Results of H1are given for direct path model without introducing mediator. 
Table 5 and figure 2 contains the standardized regression coefficients for the hypothesized model. Beta coefficients are significant at 0.01 . The results indicate that $71 \%$ increase in the innovative work behavior is caused due to participative leadership. In the same way, participative leadership leads to a $62 \%$ increase in employee commitment to change, whereas employee commitment to change is responsible for $51 \%$ increase in the innovative work behavior. Hence, $\mathrm{H} 1, \mathrm{H} 2$, and $\mathrm{H} 3$ are proved. The results indicate that employee commitment to change mediates the relationship between participative leadership and innovative work behavior. Sobel test statistics are also signification. Hence, $\mathrm{H} 4$ which is the mediation hypothesis is proved as it is the case of partial mediation.

Table 6: Moderation Results

\begin{tabular}{|c|c|c|c|c|}
\hline & \multicolumn{4}{|c|}{ Employee Commitment to Change } \\
\hline & $\beta$ & $\mathrm{SE}$ & LLCI & ULCI \\
\hline Constant & $3.81^{* * *}$ & .05 & 3.69 & 3.93 \\
\hline $\mathrm{CR}$ & $0.29^{* * *}$ & .06 & 0.16 & 0.42 \\
\hline PL & $0.23^{* * *}$ & .04 & 0.14 & .31 \\
\hline CRxPL & $0.24^{* *}$ & .05 & 0.13 & 0.34 \\
\hline$\Delta \mathrm{R}^{2}$ due to Interaction & \multicolumn{4}{|c|}{$0.04^{* * *}$} \\
\hline $\mathrm{F}$ & \multicolumn{4}{|c|}{20.78} \\
\hline \multicolumn{5}{|c|}{$\begin{array}{l}\text { Conditional Effects of Moderator between Participative Leadership and Employee Commitment t } \\
\text { Change (Slope Test) }\end{array}$} \\
\hline Moderator Change Readiness & \multicolumn{4}{|c|}{ Employee Commitment to Change } \\
\hline-.90 & $.01^{* * *}$ & .06 & -0.11 & .14 \\
\hline .00 & $.23^{* * *}$ & .04 & 0.14 & .31 \\
\hline+.90 & $.45^{* * *}$ & .06 & 0.32 & .58 \\
\hline
\end{tabular}

$\mathrm{N}=352$ Unstandardized regression coefficients are reported

$\mathrm{PL}=$ Participative Leadership; CR: Change Readiness; EC2C = Employee Commitment to Change; IWB = Innovative Work Behavior

Bootstrap sample size $=5,000$. $L L=$ lower limit; $\mathrm{CI}=$ confidence interval; $\mathrm{UL}=$ upper limit

Table 6 contains the results of moderation analysis which was done by using model 1 of Process Macro by Hayes. The value for change in R-square due to interaction is $0.4 \%$. Beta coefficient for conditional effect shows that the impact of participative leadership on employee commitment to change increases by $45 \%$ in case of high change readiness. The beta coefficient which is 0.45 is significant at 0.001 . This leads to the acceptance of $\mathrm{H} 5$. 


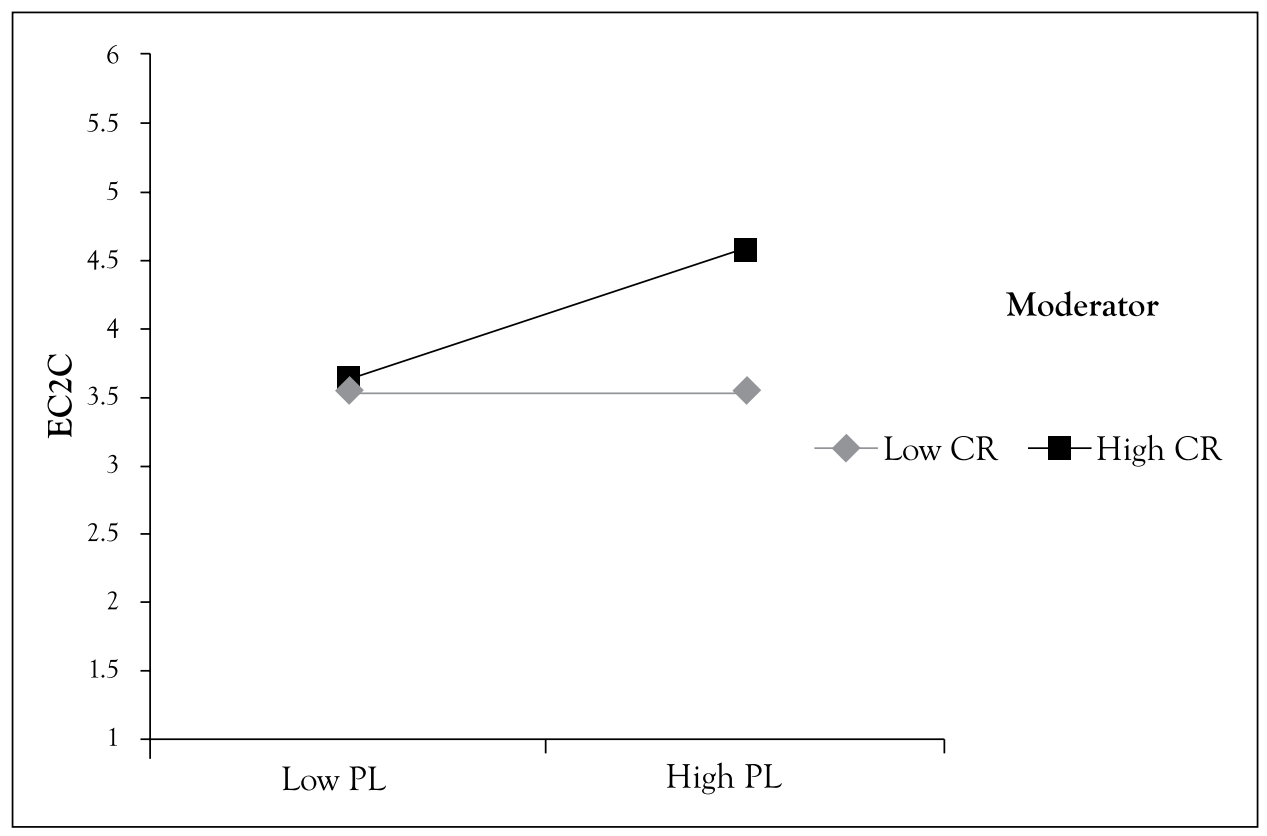

Figure 2: Moderation Graph

Figure 3 shows the moderation graph. It is clear from the figure that the impact of participative leadership on employee commitment to change increases in case of high change readiness.

Table 7: Moderated Mediation Results Across Levels of Change Readiness

\begin{tabular}{|c|c|c|c|c|}
\hline \multicolumn{5}{|c|}{ Conditional Indirect Effects of CR on Innovative Work Behavior through EC2C } \\
\hline & \multicolumn{4}{|c|}{ Change Readiness } \\
\hline Employee Commitment to Change & Boot Indirect Effect & SE & LLCI & ULCI \\
\hline-1 SD(-.90) & -0.02 & .03 & -.10 & .05 \\
\hline M (.00) & 0.10 & .02 & .05 & .15 \\
\hline+1 SD(.90) & 0.04 & .04 & .14 & .31 \\
\hline
\end{tabular}

$\mathrm{N}=352$ Unstandardized regression coefficients are reported

Bootstrap sample size $=5,000$. $L L=$ lower limit; $\mathrm{CI}=$ confidence interval; $\mathrm{UL}=$ upper limit

Table 7 contains the results of moderated mediation. The beta coefficient for the conditional indirect effect of participative leadership on innovative work behavior in case of high change readiness is 0.04 which proves that the indirect impact of participative leadership on innovative work behavior via employee commitment to change increases up to $4 \%$ in the case of higher change readiness as compared to lower change readiness. This proves moderated mediation hypothesis. 


\section{Conclusion}

The purpose of the current study was to check the impact of participative leadership on innovative work behavior with mediating role of employee commitment to change. This study also hypothesized that change readiness moderates the relationship between participative leadership and employee commitment to change such that employee with high change readiness are more likely to show commitment to change under a participative leadership. Also hypothesized in the study was the moderated mediation hypothesis. After completing the analysis by using different statistics including Herman's one-factor test, structural equation modeling, moderation analysis and moderated mediation analysis, it is proved that participative leadership leads to an increase in the innovative work behavior among employees and this relationship is partially mediated by employee commitment to change. In addition, change readiness moderates the relationship between participative leadership and employee commitment to change such that the relationship becomes strengthened in the presence of high change readiness among employees. The moderated mediation hypothesis is also proved which shows that change readiness moderates between participative leadership and employee commitment to change which then mediates between participative leadership and innovative work behavior. These results are in accordance with the past researches which indicated that employees working under a positive leadership style are more likely to show positive outcomes (Jong \& Hartog, 2007; Avey, Hughes, Norman \& Luthans, 2008; Fong \& Snape, 2015; Nelson, 2014). The results of the current study also validate social learning theory which posits that people learn from their environment by observing the behavior of others and repeating it (Bandura, 1977). When leaders give employees with the opportunity to participate in routine tasks and give their opinion in decision making then employees also start taking part in the betterment of the organization actively resulting in an increase in the commitment to change as a result of which their innovative work behavior increases.

\subsection{Discussion}

With the increase in competition, organizational are striving hard to get the competitive edge. Innovative work behavior has become an interesting topic for researchers as well as academicians as it leads to several positive employee and organizational outcomes. The current study combines leadership research with innovative work behavior by testing the moderation and mediation mechanism through which participative leadership leads to innovative work behavior. The results of the current study reveal that the commitment of employees working under a participative leader increases as a result of which they are more likely to show innovative work behavior. It also proves that employees with change readiness show increased commitment to change under a participative leader. 


\subsection{Limitations and Future Research}

Like any other study, the current research has several limitations. Firstly, data is self-reported which may cause common method bias. However, Herman's test is done and data is collected in three waves to decrease the common method bias. Another limitation pertains to the selection of only one sector that is service sector. One possible limitation of the study is presence of only single dependent variable. Like every concept, participative leadership has two sides, a positive one and a negative one. Of possible limitation of our study is that we have only highlighted the positive side of participative leadership. Participative leadership believes in involving employees throughout the decision making process. Though, it increases their motivation and commitment towards the organization as proved in several studies (Somech, 2006; Sauer, 2011). However it is not always a good leadership style (Mohammad \& Hossein, 2006). Participative leadership may cause delays in the decision making process. This is mainly because a large number of people are taking part in the decision making process. Involvement of employees in the decision making process may also raise security issues as employees are well aware of the action plan to be followed by the organization right from the initial stage. Hence, future researchers must take into account the dark side of participative leadership. This will help organizations in taking a responsible decision when it comes to choosing the right leadership style. Future researchers should conduct a longitudinal study to avoid common method bias. It will also be fruitful to check the impact of participative leadership on innovative work behavior in small and medium enterprises or entrepreneurial ventures as the nature of these businesses require higher level of innovation and innovative work behavior. Another recommendation for future researchers is to test the other mediating and moderating mechanisms that can better explain the relationship between participative leadership and employee outcomes. Different personality types like big five can also be studied with participative leadership and its outcomes.

\subsection{Theoretical and Practical Implications}

The current study adds to the existing body of knowledge on participative leadership as well as innovative work behavior by testing the unique moderating and mediating mechanism. Employee commitment to change is taken as a mediator which is itself an interesting topic for research as organizational change is becoming very common mainly because of rapidly changing working conditions and tough market competition. This study proves that when leaders follow participative leadership style then employees feel more committed to change and this increases their innovative work behavior. These results are supported by social learning theory which talks about the process of learning in which employees observe others in their surroundings, feel motivated and start repeating the observed behavior. 
This study gives several important guidelines to businessmen and practitioners, as well as, entrepreneurs. The first important contribution of this study is that it has proved that businessmen must allow their employees to participate in daily activities as this not only increases their commitment to change but also motivate them to show innovative work. This is particularly important for those companies which are either currently going through any type of organizational change or are planning to go for a change. Another important lesson practitioners may take from the results is the fact that those employee who are ready for change are more likely to feel commitment at the time of change. Hence, practitioners should develop strategies to increase change readiness among employees. In addition to this, top leaders should give part to employees' in decision making as employees observe their leaders and follow their behavior.

\section{References}

Akram, T., Lei, S., \& Haider, M. J. (2016). The impact of relational leadership on employee innovative work behavior in IT industry of China. Arab Economic and Business Journal, 11(2), 153-161.

Anderson, J. C., \& Gerbing, D. W. (1988). Structural equation modeling in practice: A review and recommended two-step approach. Psychological Bulletin, 103(3), 411.

Archibugi, D., Filippetti, A., \& Frenz, M. (2013). Economic crisis and innovation: Is destruction prevailing over accumulation? Research Policy, 42(2), 303-314.

Arnold, J. A., Arad, S., Rhoades, J. A., \& Drasgow, F. (2000). The empowering leadership questionnaire: The construction and validation of a new scale for measuring leader behaviors. Journal of Organizational Behavior, 249-269.

Arnold, J. A., Arad, S., Rhoades, J. A., \& Drasgow, F. (2000). The empowering leadership questionnaire: The construction and validation of a new scale for measuring leader behaviors. Journal of Organizational Behavior, 249-269.

Asmawi, A., Rahim, M. F. A., \& Zainuddin, M. N. (2015). A study of leadership styles and organizational commitment in a Malaysian Private University. Advanced Science Letters, 21(6), 1944-1947.

Avey, J. B., Hughes, L. W., Norman, S. M., \& Luthans, K. W. (2008). Using positivity, transformational leadership and empowerment to combat employee negativity. Leadership $\mathcal{E}$ Organization Development Journal, 29(2), 110-126.

Bandura, A. (1977). Social learning theory.

Bandura, A. (1978). Social learning theory of aggression. Journal of communication, 28(3), 12-29.

Barrett, M., Davidson, E., Prabhu, J., \& Vargo, S. L. (2015). Service innovation in the digital age: key contributions and future directions. MIS quarterly, 39(1), 135-154.

Becker, T. E. (2005). Potential problems in the statistical control of variables in organizational research: 
A qualitative analysis with recommendations. Organizational Research Methods, 8(3), 274-289.

Benoliel, P., \& Somech, A. (2014). The health and performance effects of participative leadership: Exploring the moderating role of the Big Five personality dimensions. European Journal of Work and Organizational Psychology, 23(2), 277-294.

De Jong, J. P., \& Den Hartog, D. N. (2007). How leaders influence employees' innovative behaviour. European Journal of Innovation Management, 10(1), 41-64.

De Jong, J. P., \& Den Hartog, D. N. (2008). Innovative work behavior: Measurement and validation. EIM Business and Policy Research, 1-27.

Delgadová, E., Gullerová, M., \& Ivanová, E. (2017). Recruitment and selection processes in Slovak enterprises and multinational corporations. International Journal of Organizational Leadership, 6(2), 211.

Delgadová, E., Gullerová, M., \& Ivanová, E. (2017). Recruitment and selection processes in Slovak enterprises and multinational corporations. International Journal of Organizational Leadership, 6(2), 211.

Donate, M. J., \& de Pablo, J. D. S. (2015). The role of knowledge-oriented leadership in knowledge management practices and innovation. Journal of Business Research, 68(2), 360-370.

Fong, K. H., \& Snape, E. (2015). Empowering leadership, psychological empowerment and employee Outcomes: Testing a multi-level mediating model. British Journal of Management, 26(1), 126-138.

Herscovitch, L., \& Meyer, J. P. (2002). Commitment to organizational change: Extension of a three-component model. Journal of Applied Psychology, 87(3), 474.

Hogan, S. J., \& Coote, L. V. (2014). Organizational culture, innovation, and performance: A test of Schein's model. Journal of Business Research, 67(8), 1609-1621.

Holt, D. T., Armenakis, A. A., Feild, H. S., \& Harris, S. G. (2007). Readiness for organizational change: The systematic development of a scale. The Journal of Applied Behavioral Science, 43(2), 232-255.

Kim, S. (2002). Participative management and job satisfaction: Lessons for management leadership. Public Administration Review, 62(2), 231-241.

Kwahk, K. Y., \& Lee, J. N. (2008). The role of readiness for change in ERP implementation: Theoretical bases and empirical validation. Information $\mathcal{E}$ Management, 45(7), 474-481.

Lam, C. K., Huang, X., \& Chan, S. C. (2015). The threshold effect of participative leadership and the role of leader information sharing. Academy of Management Journal, 58(3), 836-855.

Lumbasi, G. W., K’Aol, G. O., \& Ouma, C. A. (2016). The Effect of Participative Leadership Style on the Performance of COYA Senior Managers in Kenya.

Madrid, H. P., Patterson, M. G., Birdi, K. S., Leiva, P. I., \& Kausel, E. E. (2014). The role of weekly high Пactivated positive mood, context, and personality in innovative work behavior: A multilevel and interactional model. Journal of Organizational Behavior, 35(2), 234-256. 
Madsen, S. R., Miller, D., \& John, C. R. (2005). Readiness for organizational change: Do organizational commitment and social relationships in the workplace make a difference? Human Resource Development Quarterly, 16(2), 213.

Miao, Q., Newman, A., \& Huang, X. (2014). The impact of participative leadership on job performance and organizational citizenship behavior: distinguishing between the mediating effects of affective and cognitive trust. The International Journal of Human Resource Management, 25(20), 2796-2810.

Miao, Q., Newman, A., Schwarz, G., \& Xu, L. (2013). Participative leadership and the organizational commitment of civil servants in China: the mediating effects of trust in supervisor. British Journal of Management, 24(S1).

Michaelis, B., Stegmaier, R., \& Sonntag, K. (2010). Shedding light on followers' innovation implementation behavior: The role of transformational leadership, commitment to change, and climate for initiative. Journal of Managerial Psychology, 25(4), 408-429.

Mohammad Mosadegh Rad, A., \& Hossein Yarmohammadian, M. (2006). A study of relationship between managers' leadership style and employees' job satisfaction. Leadership in Health Services, 19(2), $11-28$.

Mowday, R. T., Steers, R. M., \& Porter, L. W. (1979). The measurement of organizational commitment. Journal of vocational behavior, 14(2), 224-247.

Nelson, A. D. (2014). The Role of Leader Communication Patterns, LMX, and Interactional Justice in Employee Emotional Exhaustion and Outcomes.

Pearce, C. L., \& Sims Jr, H. P. (2002). Vertical versus shared leadership as predictors of the effectiveness of change management teams: An examination of aversive, directive, transactional, transformational, and empowering leader behaviors. Group dynamics: Theory, Research, and Practice, 6(2), 172.

Podsakoff, P. M., MacKenzie, S. B., Lee, J. Y., \& Podsakoff, N. P. (2003). Common method biases in behavioral research: a critical review of the literature and recommended remedies. Journal of Applied Psychology, 88(5), 879.

Rafferty, A. E., \& Restubog, S. L. D. (2010). The impact of change process and context on change reactions and turnover during a merger. Journal of Management, 36(5), 1309-1338.

Sauer, S. J. (2011). Taking the reins: the effects of new leader status and leadership style on team performance. Journal of Applied Psychology, 96(3), 574.

Scott, S. G., \& Bruce, R. A. (1994). Determinants of innovative behavior: A path model of individual innovation in the workplace. Academy of Management Journal, 37(3), 580-607.

Shanker, R., Bhanugopan, R., Van der Heijden, B. I., \& Farrell, M. (2017). Organizational climate for innovation and organizational performance: The mediating effect of innovative work behavior. Journal of Vocational Behavior, 100, 67-77. 
Somech, A. (2005). Directive versus participative leadership: Two complementary approaches to managing school effectiveness. Educational administration quarterly, 41(5), 777-800.

Somech, A. (2006). The effects of leadership style and team process on performance and innovation in functionally heterogeneous teams. Journal of management, 32(1), 132-157.

Somech, A., \& Wenderow, M. (2006). The impact of participative and directive leadership on teachers' performance: The intervening effects of job structuring, decision domain, and leader-member exchange. Educational Administration Quarterly, 42(5), 746-772

Strom, D. L., Sears, K. L., \& Kelly, K. M. (2014). Work engagement: The roles of organizational justice and leadership style in predicting engagement among employees. Journal of Leadership $\mathcal{E}$ Organizational Studies, 21(1), 71-82.

Trivisonno, M., \& Barling, J. (2016). 22. Organizational leadership and employee commitment. Handbook of Employee Commitment, 305.

Turner Parish, J., Cadwallader, S., \& Busch, P. (2008). Want to, need to, ought to: Employee commitment to organizational change. Journal of Organizational Change Management, 21(1), 32-52.

Van Dam, K., Oreg, S., \& Schyns, B. (2008). Daily work contexts and resistance to organisational change: The role of leader-member exchange, development climate, and change process characteristics. Applied Psychology, 57(2), 313-334. 